DOI: http://dx.doi.org/10.31558/2307-2296.2019.1.18

УДК 336.2

Юрчишена Л.В., к.е.н., доцент, доцент кафедри фінансів і банківської справи Донецького національного університету ім. Василя Стуса

Саницька О.Ю., магістрант Донецького національного університету ім. Василя Стуса

\title{
АНАЛІЗ ЄДИНОГО ПОДАТКУ У ФОРМУВАННІ ДОХОДІВ МІСЦЕВИХ БЮДЖЕТІВ УКРАЇНI
}

У статті проаналізовано динаміку і взаємозв'язок зміни суб'єктів малого підприємництва і надходжень єдиного податку в Україні, визначено фіскальне значення єдиного податку в доходах місцевого бюджету, оцінено структуру доходів місцевих бюджетів, виконання планових показників доходів місцевих бюджетів, розглянуто взаємозв'язок інтересів держави i малого бізнесу. Розроблено концепцію адміністрування єдиного податку в Україні, метою якої $є$ удосконалення процесу адміністрування єдиного податку, сприяння розвитку малого бізнесу, збільшення надходжень в місцеві бюджети, зменшення тіньового сектору економіки, безробіття i зниження рівня соціальної напруги в Україні.

Ключові слова: єдиний податок, спрощена система оподаткування, місцеві бюджети, суб'єкти малого підприємництва, концепція адміністрування єдиного податку.

Рис. 4, Табл. 3, Літ. 9.

\section{Юрчишена Л.В., Саницкая О.Ю.}

\section{АНАЛИЗ ЕДИНОГО НАЛОГА В ФОРМИРОВАНИИ ДОХОДОВ МЕСТНЫХ БЮДЖЕТОВ УКРАИНЫ}

В статье проанализирована динамика и взаимосвязь изменения субъектов малого предпринимательства и поступлений единого налога в Украине, определено фискальное значение единого налога в доходах местного бюджета, сделана оценка структуры доходов местных бюджетов, выполнения плановых показателей доходов местных бюджетов, рассмотрена взаимосвязь интересов государства и малого бизнеса. Разработана концепция администрирования единого налога в Украине, целью которой является совершенствование процесса администрирования единого налога, содействие развитию малого бизнеса, увеличение поступлений в местные бюджеты, уменьшение теневого сектора экономики, безработицы и снижение уровня социальной напряженности в Украине.

Ключевые слова: единый налог, упрощенная система налогообложения, местные бюджеты, субъекты малого предпринимательства, концепция администрирования единого налога.

\section{Yurchishena L., Sanytska O.}

\section{ANALYSIS OF THE SINGLE TAX IN THE LOCAL BUDGETS OF UKRAINE}

The article analyzes the dynamics and interrelation of changes of small business entities and single tax revenues in Ukraine, determines the fiscal importance of a single tax in local budget revenues, estimates the structure of local budget revenues, the implementation of local budget revenue indicators, considers the interrelationship and small business. The concept of single tax administration in Ukraine has been developed with the purpose of improving the single tax administration process, promoting small business development, 
increasing local budget revenues, reducing the shadow economy, unemployment and reducing social tension in Ukraine.

Keywords: single tax, simplified taxation system, local budgets, small business entities, single tax administration concept.

Постановка проблеми. Бюджетна децентралізація місцевого самоврядування дає можливість ефективно використовувати ресурсний, трудовий i фінансовий потенціал регіону, створюючи комфортні умови для розвитку бізнес-клімату регіону. Стартовою площадкою для малого і середнього бізнесу є мікро підприємництво, яке потребує пільгових, необтяжливих умов функціонування і оподаткування, що сприяє нарощенню фінансово-економічного потенціалу.

Спрощена системи оподаткування в Україні має ряд проблем, які вимагають законодавчого та економічного регулювання, але поєднання інтересів малого бізнесу i держави, зумовить отримання подвійного ефекту - збільшення надходжень від єдиного податку до місцевих бюджетів i зростання можливостей щодо здійснення підприємницької діяльності як молоддю, так і економічно активним населенням. Тому, аналіз надходжень єдиного податку до місцевих бюджетів дасть можливість виявити проблеми та обгрунтувати концепцію спрямовану на покращення процесу адміністрування єдиного податку в Україні.

Аналіз останніх досліджень і публікацій. Аналіз фінансового забезпечення місцевих бюджетів за рахунок надходжень від єдиного податку, а також взаємодію бізнесу і влади 3 метою розвитку малого і середнього бізнесу досліджували такі науковці, як Коба О.В., Ковальчук І.С., Кугій А.А., Сокотенюк С.М., Лозовський О.М. та інші аналітики-практики.

Визначення невирішених питань в обраній для дослідження проблемі. Спрощена система оподаткування має як позитивні, так і негативні ефекти. 3 однією сторони, дає можливість розвиватися малому бізнесу, а з іншої $є$ інструментом, який використовує великий бізнес для зниження податкового навантаження шляхом його дроблення на малих підприємців, зменшення бази оподаткування, приховування реальних доходів тощо. Всі ці проблеми призводять до зменшення фінансової спроможності місцевих бюджетів за рахунок недоотримання податкових платежів, тому потребують подальшого дослідження і визначення шляхів вирішення.

Метою статті $\epsilon$ визначення тенденцій наповнення місцевих бюджетів за рахунок єдиного податку, що враховується при розробці концепції вдосконалення адміністрування єдиного податку в Україні.

Виклад основного матеріалу. Фінансовою базою органів місцевого самоврядування $\epsilon$ місцеві бюджети, джерелом наповнення яких $\epsilon$ податкові i неподаткові надходження, тому зміцнення і розширення економічного потенціалу регіону, територіальних громад реалізується завдяки виявленню і пошуку резервів фінансових ресурсів. Формуванні і плануванні кошторисів місцевих бюджетів повинно здійснюватися на основі бюджетної декларації, яка визначає параметри бюджету країни і напрямки бюджетної політики на наступний рік. В Україні існує негативна історія іiі використання, так як уряд 32014 року iї не ухвалював, що порушує бюджетне законодавство.

Надходження єдиного податку в місцеві бюджети України залежить від ряду чинників, зокрема, одним із основних є зміна кількості суб'єктів малого підприємництва в Україні. 
Суб'єкти малого підприємництва в Україні здійснюють господарську діяльність, як юридичні особи і фізичні особи підприємці, кількість яких є значно більшою i становить орієнтовно 1,5-1,6 млн. осіб, що майже в 5 раз перевищує кількість малих підприємств-юридичних осіб. Суттєве зменшення суб'єктів малого підприємництва в Україні відбулося в 2016 році, юридичних осіб на 36660 одиниць, фізичних осібпідприємців на 71717 од, негативна тенденція зберігається і в 2017 р., що зумовило скорочення ще 92358 осіб.

Таблиця 1 - Динаміка зміни суб'єктів малого підприємництва в Україні

\begin{tabular}{|c|c|c|c|c|}
\hline Показник & 2014 p. & $2015 \mathrm{p}$. & $2016 \mathrm{p}$. & $2017 \mathrm{p}$. \\
\hline \multicolumn{5}{|c|}{ Малі підприємства - юридичні особи: } \\
\hline $\begin{array}{l}\text { - фактична кількість, од } \\
\text { - зміна, од. }\end{array}$ & $\begin{array}{c}324598 \\
-\end{array}$ & $\begin{array}{c}327814 \\
3216\end{array}$ & $\begin{array}{l}291154 \\
-36660\end{array}$ & $\begin{array}{c}322920 \\
31766\end{array}$ \\
\hline $\begin{array}{l}\text { - у розрахунку на } 10 \text { тис. осіб } \\
\text { наявного населення, од. }\end{array}$ & 76 & 77 & 68 & 76 \\
\hline $\begin{array}{l}\text { - обсяг реалізованої продукції } \\
\text { (робіт, послуг), млн. грн. }\end{array}$ & 705000,5 & 937112,8 & 1177385,2 & 14820000,7 \\
\hline \multicolumn{5}{|c|}{ Фізичні особи-підприємиі: } \\
\hline $\begin{array}{l}\text { - фактична кількість, од } \\
\text { - зміна, од. }\end{array}$ & $\begin{array}{c}1591160 \\
-\end{array}$ & $\begin{array}{c}1630878 \\
39718\end{array}$ & $\begin{array}{l}1559161 \\
-71717\end{array}$ & $\begin{array}{c}1466803 \\
-92358\end{array}$ \\
\hline $\begin{array}{l}\text { - } \text { у розрахунку на } 10 \text { тис. осіб } \\
\text { наявного населення, од. }\end{array}$ & 370 & 381 & 365 & 345 \\
\hline $\begin{array}{l}\text { - обсяг реалізованої продукції (робіт, } \\
\text { послуг), млн. грн. }\end{array}$ & 289042,3 & 397473,3 & 489204,6 & 604336,7 \\
\hline $\begin{array}{l}\text { Єдиний податок для суб’єктів малого } \\
\text { підприємництва, млн. грн. } \\
\text { темп приросту, \% }\end{array}$ & 7413,25 & $\begin{array}{c}10975,09 \\
48,05\end{array}$ & $\begin{array}{c}17167,10 \\
56,42\end{array}$ & $\begin{array}{c}23388,30 \\
36,24\end{array}$ \\
\hline
\end{tabular}

*Джерело: складено авторами за даними $[2,3]$

Незважаючи на суттєві скорочення кількості суб'єктів малого підприємництва темп приросту єдиного податку до місцевих бюджетів зростає в 2015-2016 pp. i становить 48 і 56 \% відповідно, в 2017 р. даний показник знизився і становить $36 \%$. Позитивна динаміка відбулася за рахунок впливу інфляції, збільшення бази оподаткування для 1-ї і 2-ї групи, прожиткового мінімуму працездатних осіб i мінімальної заробітної плати, зростання доходів платників третьої групи в абсолютному вираженні, зміни нормативної грошової оцінки землі для 
сільгоспвиробників.

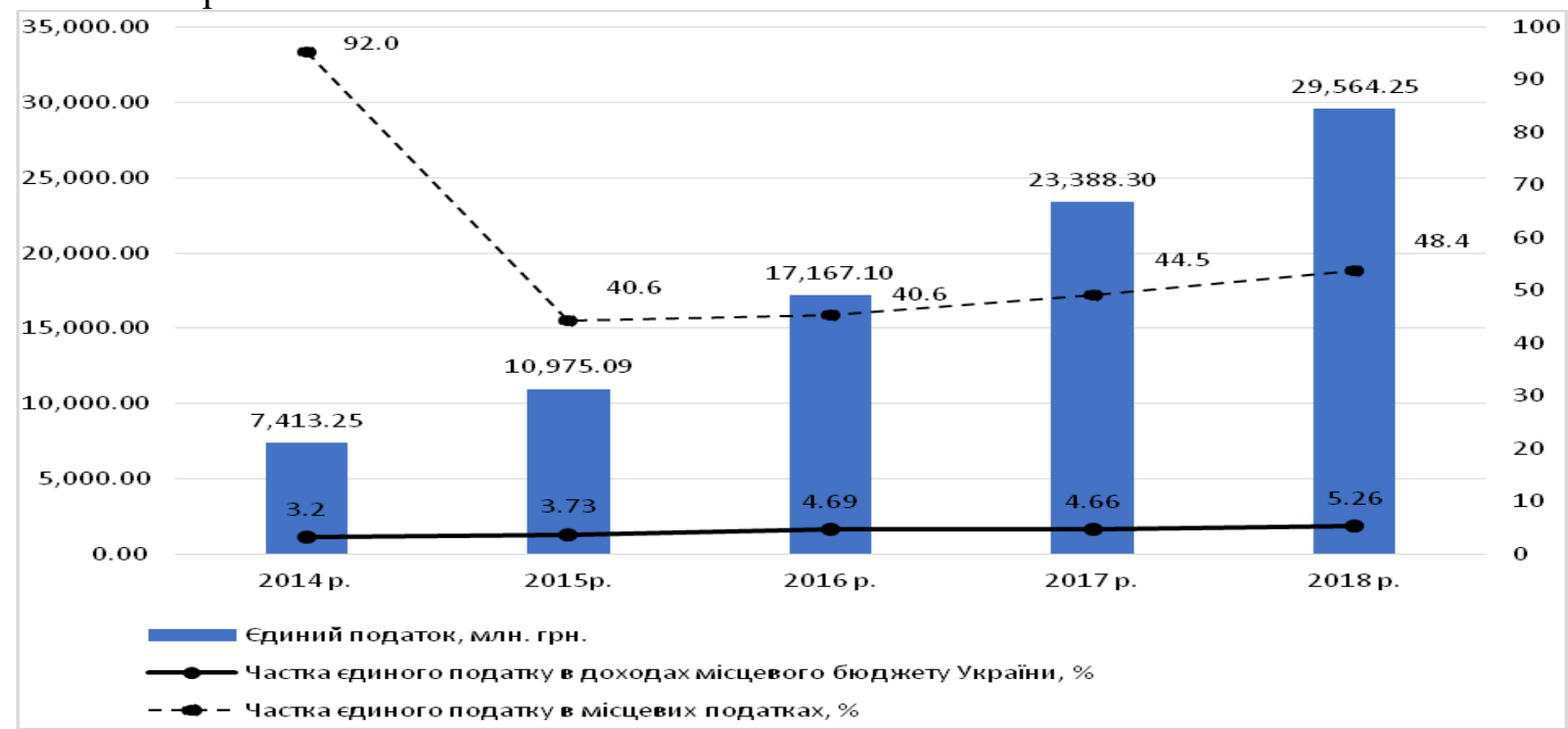

Рисунок 1 - Фіскальне значення єдиного податку в доходах місцевого бюджету України (побудовано за даними [2, 3])

За даними рис. 1 спостерігається стрімке зростання абсолютних показників єдиного податку в Україні з 7413,25 млн. грн. в 2014 р. до 29564,25 млн. грн в 2018 р., проте якщо порівнювати їх з часткою єдиного податку в структурі доходів місцевого бюджету України, то питома вага даного податку зросла лише на $2 \%$ за період дослідження, і становить 5,26 \%. В структурі місцевих податків єдиний податок займає значну питому вагу, яка становить 40-48 \% в 2015-2018 рр. поступово зміцнюючи свої позиції.

Таблиця 2 - Динаміка зміни податків в доходах місцевого бюджету

\begin{tabular}{|l|c|c|c|c|c|}
\hline \multicolumn{1}{|c|}{ Показник } & 2014 p. & $2015 \mathrm{p}$. & $2016 \mathrm{p}$. & 2017 p. & $2018 \mathrm{p}$. \\
\hline $\begin{array}{l}\text { Доходи місцевого бюджету, } \\
\text { млн. грн }\end{array}$ & 231702,01 & 294460,23 & 366143,12 & 502098,31 & 562421,81 \\
\hline темп приросту, \% & - & 27,09 & 24,34 & 37,13 & 12,01 \\
\hline $\begin{array}{l}\text { Податкові надходження, } \\
\text { млн. грн }\end{array}$ & 87333,67 & 98218,36 & 146902,25 & 201005,13 & 232532,88 \\
\hline темп приросту, \% & - & 12,46 & 49,57 & 36,83 & 15,69 \\
\hline Місцеві податки, млн. грн & 8055,15 & 27041,19 & 42261,50 & 52586,84 & 61026,45 \\
\hline темп приросту, \% & - & 235,70 & 56,29 & 24,43 & 16,05 \\
\hline Сдиний податок, млн. грн & 7413,25 & 10975,09 & 17167,10 & 23388,30 & 29564,25 \\
\hline темп приросту, \% & - & 48,05 & 56,42 & 36,24 & 26,41 \\
\hline
\end{tabular}

*Джерело: складено авторами за даними $[2,3]$

Доходи місцевих бюджетів України мають тенденцію щодо зростання за останні п’ять років в два рази з 231702,01 до 562421,81 млн. грн., проте дана динаміка не супроводжується стійкими темпами приросту. Зростання доходів місцевих бюджетів України в 2017 р. на 37,13 \% відбулося за рахунок збільшення обсягу податкових надходжень на 36,83 \%, що супроводжується процесами децентралізації в країні, передання більше повноважень i можливостей щодо управління фінансовою 
спроможністю територіальних громад, органів місцевого самоврядування [9]. Дані процеси нерозривно пов'язані із зростанням надходжень від єдиного податку, переважно за рахунок збільшення бази оподаткування.

Найвищі темпи приросту податкових надходжень до місцевих бюджетів спостерігалися в 2016 році майже на 50 \% і досягли 146902,25 млн. грн., в тому числі за рахунок зростання надходжень від єдиного податку на $56 \%$.

Аналіз формування доходів місцевих бюджетів за рахунок податкових надходжень, показує позитивний вплив фінансової децентралізації, податкової і бюджетної реформи в Україні, що забезпечило зростання податкового потенціалу, проте фіскальна ефективність реформ в Україні є досить неоднозначною, хоча і має позитивний вплив на бюджет країни.

В структурі доходів місцевих бюджетів визначальне місце займають податкові надходження, питома вага яких становить в 2018 р. 41,34 \%, і починаючи 3 2015 року характеризується позитивною тенденцією, частка місцевих податків складає 9-11,5\% в 2015-2018 рр., в т. ч. єдиного податку - 3-5,3\% за період дослідження. Отже, абсолютна величина єдиного податку в місцевих бюджетах є досить значною, і має потенціал для подальшого зростання за рахунок розширення кола платників, формування сприятливих умов регіонів для розвитку малого бізнесу, і як наслідок зміцнення фінансової спроможності регіонів.

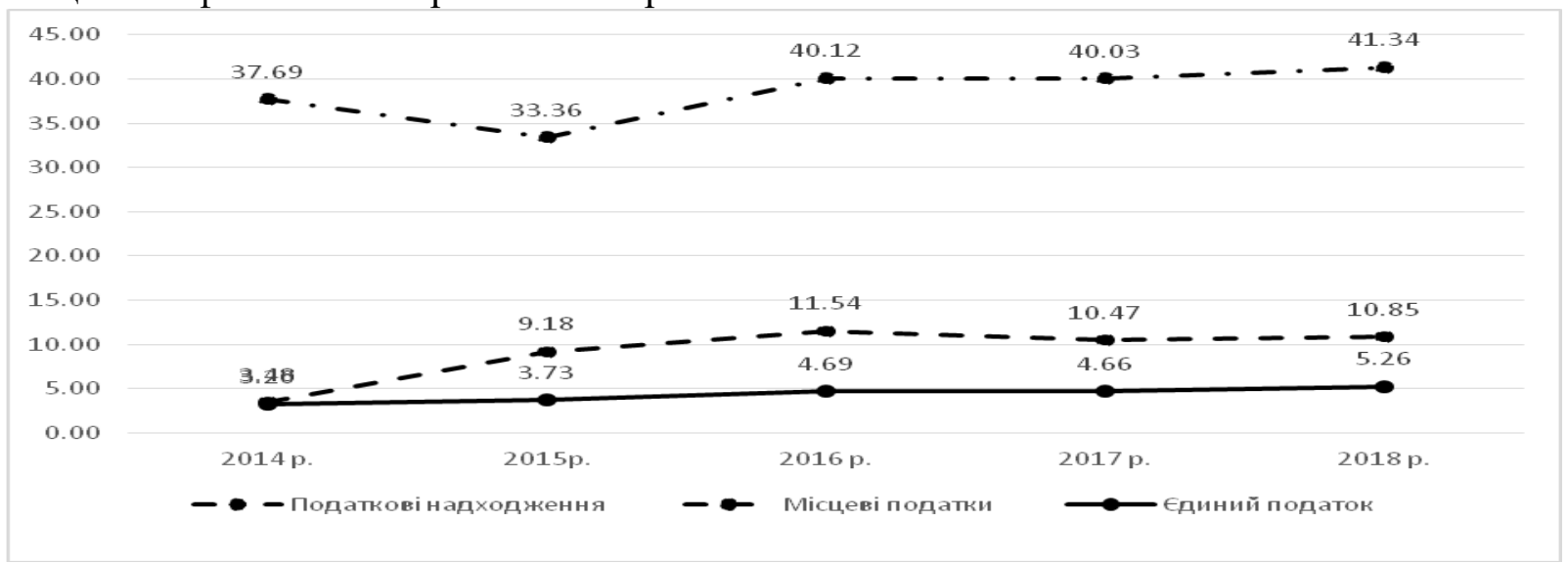

Рисунок 2 - Динаміка єдиного податку в структурі доходів місцевих бюджетів України (побудовано за даними $[2,3])$

Фінансова самостійність місцевих бюджетів, яка реалізується в рамках бюджетної децентралізації зумовлює аналіз виконання планових показників місцевих бюджетів і свідчить про ефективність виконання плану (табл. 3).

Таблиця 3 - Виконання планових надходжень доходів місцевих бюджетів України

\begin{tabular}{|l|r|r|r|r|r|}
\hline Показник & $2014 \mathrm{p}$. & $2015 \mathrm{p}$. & $2016 \mathrm{p}$. & $2017 \mathrm{p}$. & $2018 \mathrm{p}$. \\
\hline Податкові надходження & $-7246,56$ & 11549,14 & 15053,26 & 9108,59 & 2718,84 \\
\hline Місцеві податки & 148,30 & 3493,51 & 4612,66 & 2876,63 & 2126,53 \\
\hline Сдиний податок & 194,65 & 1684,75 & 2346,15 & 1808,56 & 1736,44 \\
\hline $\begin{array}{l}\text { Сдиний податок 3 юридичних осіб, } \\
\text { нарахований до 1 січня 2011 року }\end{array}$ & $-0,43$ & 0,02 & $-0,88$ & $-0,48$ & $-0,10$ \\
\hline
\end{tabular}




\begin{tabular}{|l|r|r|r|r|r|}
\hline $\begin{array}{l}\text { Сдиний податок з фізичних осіб, } \\
\text { нарахований до 1 січня 2011 року }\end{array}$ & 0,23 & 0,12 & $-0,38$ & $-0,25$ & $-0,37$ \\
\hline Єдиний податок з юридичних осіб & 54,32 & 171,01 & 371,96 & 66,78 & 138,62 \\
\hline Сдиний податок 3 фізичних осіб & 139,99 & 704,82 & 903,36 & 1192,81 & 1105,68 \\
\hline $\begin{array}{l}\text { Єдиний податок з сільгоспвиробників, } \\
\text { у яких частка сільськогосподарського } \\
\text { товаровиробництва за попередній } \\
\text { податковий (ввітний) рік дорівнює або } \\
\text { перевищує 75 відсотків }\end{array}$ & & & & & \\
\hline Всього & 0 & 808,79 & 1072,09 & 549,70 & 492,62 \\
\hline
\end{tabular}

*Джерело: складено авторами за даними $[2,3]$

Дані таблиці 3 показують, що в 2014 р. планові показники податкових надходжень не виконані на суму 7246,56 млн. грн., що вплинуло на недоотримання місцевими бюджетами України 21304,78 млн. грн. Планові надходження єдиного податку виконані повністю як в цілому, так і за рахунок фізичних і юридичних осіб. Тенденції щодо перевиконання планових показників єдиного податку зумовлені надходженнями від фізичних осіб підприємців в 2014 році на 139,99 млн. грн, в 20172018 рр. на 1192,81-1105,68 млн. грн відповідно. Перевиконання надходжень єдиного податку від юридичних осіб є значно меншими в 2017-2018 рр. і становить 66,78-138,62 млн. грн відповідно, це стосується платників, які знаходяться на 3-й групі оподаткування.

Фактичні надходження від платників 4-ї групи - сільськогосподарських товаровиробників, у яких частка сільськогосподарського товаровиробництва за попередній податковий (звітний) рік дорівнює або перевищує $75 \%$ становить на 1072,09 млн. грн більше порівняно з 2016 роком, в наступні періоди перевищення $\epsilon$ нижчим і становить 549,7-492,62 млн. грн відповідно за 2017-2018 рр.

Динаміка надходжень єдиного податку від юридичних і фізичних осіб у 20142018 рр. наведена на рис. 3.

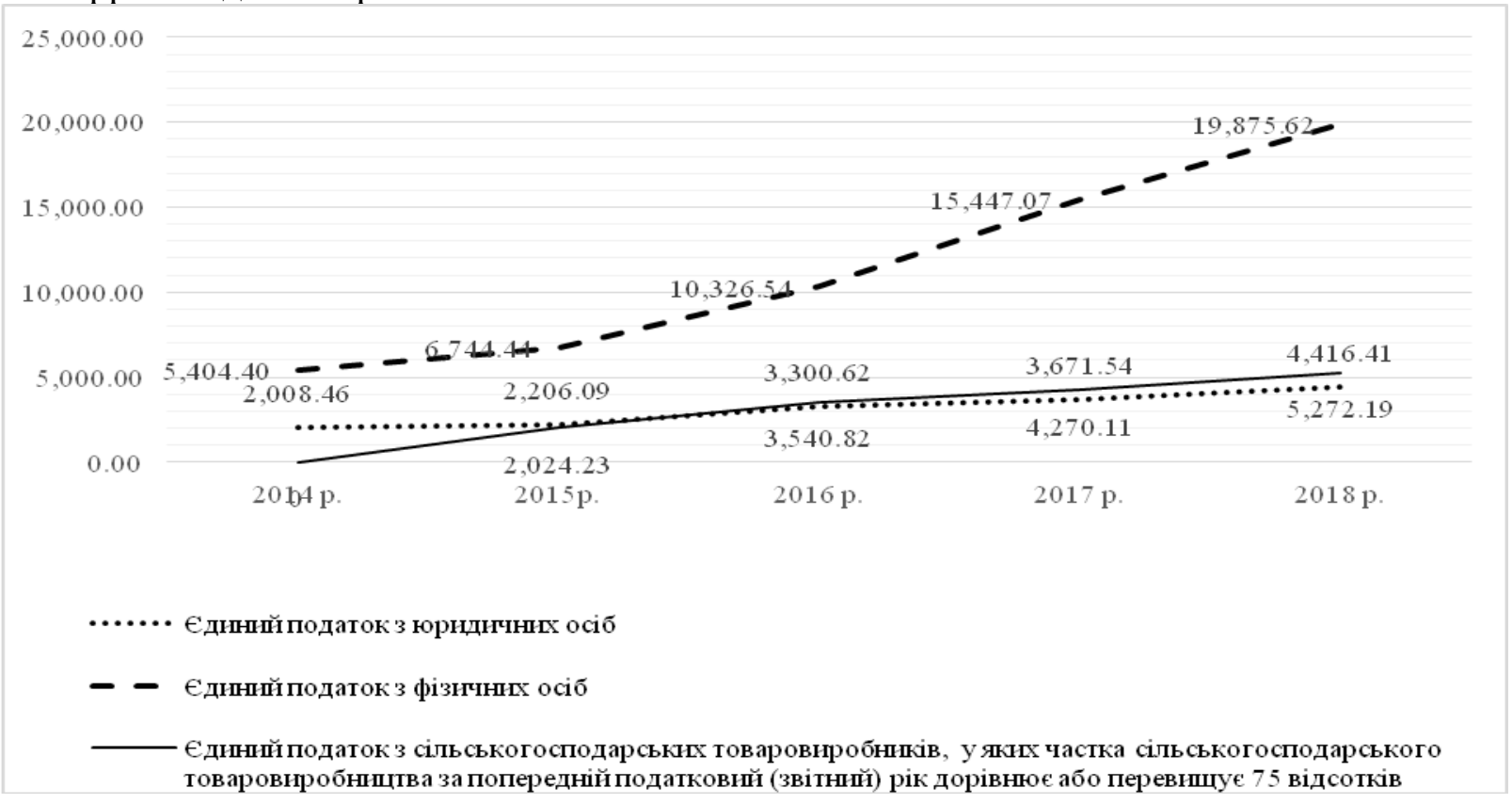

Рисунок 3 - Динаміка надходжень єдиного податку до місцевих бюджетів України (побудовано за даними [2, 3]) 
Динаміка надходжень єдиного податку 3 фізичних осіб спостерігається $\epsilon$ позитивною протягом всього періоду дослідження. Зростання податкових надходжень зумовлено не зростанням кількості платників, так як кількість платників-фізичних осіб зменшилася в 2017-2018 рр. (табл. 1), а збільшенням бази оподаткування і доходів платників 3-ї групи.

Щодо надходжень єдиного податку від юридичних осіб і сільськогосподарських товаровиробників, то їх суми зростають при одночасному зменшенні кількості платників.

Оптимізацію балансу інтересів між державою і малим бізнесом можна реалізувати використовуючи комплекс заходів, основними з яких є:

- посилення відповідальності платників єдиного податку за використання праці працівників без оформлення трудових відносин;

- створення стимулів для місцевих органів влади в зацікавленості розвитку малого бізнесу на їх територіях;

- звільнення від оподаткування новостворених підприємств та підприємців на протязі першого року діяльності;

- прив'язка диференційованого граничного обсягу виручки, що дає право переходу на спрощену систему оподаткування, до розміру мінімальної заробітної плати або індексу інфляції з метою постійної іiі актуалізації [7].

Внесення змін до регулюючих елементів спрощеної системи оподаткування дозволить зберегти позитивну динаміку платників, усунути виявлені недоліки і закрити «лазівки», що використовуються для мінімізації податкових зобов'язань.

В теорії оподаткування існують різні концепції оподаткування, відповідно до однієї з них, суб'єкти оподаткування повинні сплачувати податки пропорційно тим вигодам, які вони отримують від держави, проте ці вигоди неможливо прямо оцінити. Відповідно до іншої концепції фізичні і юридичні особи повинні сплачувати податки залежно від розміру доходів, що притаманно третій групі платників. Недоліком $є$ те, що на практиці платники намагають занижувати обсяг отриманих доходів, і як наслідок, ухилятися від оподаткування.

Удосконалення процесу адміністрування єдиного податку в Україні повинно базуватися на концепції, яка включає мету, завдання, принципи і методи реалізації, ефективне впровадження якої дасть можливість досягти поставленої мети (рис. 4).

Метою концепції $\epsilon$ удосконалення процесу адміністрування єдиного податку, сприяння розвитку малого бізнесу, збільшення надходжень в місцеві бюджети, зменшення тіньового сектору економіки, безробіття і зниження рівня соціальної напруги в Україні.

Поставлена мета спрямована на вирішення ряду завдань:

- збалансування інтересів платників і органів місцевого самоврядування;

- формування податкової культури платників;

- доступність взаємодії платник-контролюючий орган;

- забезпечення інформаційної відкритості, чіткого, зрозумілого для платника процесу адміністрування єдиного податку;

- стимулювання підприємницької активності, створення пільгових режимів для окремих платників податків.

Принципи адміністрування єдиного податку в Україні:

1) ефективність - передбачає, що спрощена система оподаткування повинна сприяти розвитку малого бізнесу, забезпечувати додаткові інвестиції; 




Рисунок 4 - Концепція адміністрування єдиного податку в Україні

2) нейтральність - умови оподаткування не залежать від суб'єктів підприємницької діяльності, і не впливають на збільшення або зменшення конкурентоспроможності платників; 
3) прозорість - адміністрування повинно бути передбачуваним з точки зору залучення інвестиційного капіталу;

4) збалансованість - передбачає збалансування надходжень єдиного податку за рахунок визначення ставок і бази оподаткування I-IV груп платників;

5) рівномірність і зручність сплати - установлення строків сплати податків та зборів, виходячи із необхідності забезпечення своєчасного надходження коштів до бюджетів для здійснення витрат бюджету та зручності їх сплати платниками;

6) єдиний підхід до встановлення податків - визначення на законодавчому рівні усіх обов'язкових елементів податку.

Поставлені завдання в концепції реалізуються не лише на основі принципів, а за допомогою методів реалізації, які включають:

- проведення інформаційних зустрічей з платниками щодо роз'яснення питань оподаткування;

- спрощення формальних процедур адміністрування єдиного податку;

- своєчасне оприлюднення інформації на сайті Державної податкової служби і її територіальних відділень;

- розробка програм сприяння розвитку малого бізнесу в регіоні, в т. ч. практика запровадження пільгового режиму оподаткування платників

- аналіз і удосконалення місцевих регуляторних актів, ;спрощення процедури отримання дозволів/ліцензій.

Повна реалізація методів адміністрування дозволить досягти поставленої мети, в разі виявлення проблем щодо їх впровадження потрібно знову повернутися на етап формування методів і переглянути їх.

Висновки. Сучасні реалії вимагають від органів місцевого самоврядування дієвих заходів щодо розвитку і підтримки малого бізнесу, розробки програм, які б сприяли виведення суб'єктів малого бізнесу з тіні, створення нових робочих місць, зменшення обсягу трудової міграції, відтоку активної частини населення за кордон, і як наслідок зростання економічного потенціалу регіонів. Тому, збалансування інтересів бізнесу і держави, розподіл платників спрощеної системи оподаткування на юридичних і фізичних осіб, впровадження концепції адміністрування на рівні органів місцевого самоврядування зумовить підвищення фіскальної ефективності платників, і як наслідок легалізації діяльності малого бізнесу, зростання доходів місцевих бюджетів.

\section{Література:}

1. Бондарчук К. Мале підприємництво як засіб розширення сфери зайнятості економічно активного населення. Україна: аспекти праці. 2015. № 1. С. 18-24

2. Державна служба статистики України. URL: http://www.ukrstat.gov.ua.

3. Казначейська служба України. URL: http://www.treasury.gov.ua

4. Коба О. В., Шинкар Ю.Л. Порівняльний аналіз загальної та спрощеної системи оподаткування: особливості застосування, проблеми та напрями їх вирішення. Ужгород, 2019. - Вип. 25, Ч. 1. - С. 116-120.

5. Ковальчук I. С. Аналіз рівня оподаткування суб’єктів малого підприємництва в Україні. Електронне наукове фахове видання з економічних наук «Modern Economics», №5, 2017. 
6. Кугій А.А., Сокотенюк С.М. Структурний аналіз фінансового забезпечення малого підприємництва. Економічний вісник національного технічного університету України. 2015. №12. C. 238-245. URL: http://ev.fmm.kpi.ua/article/view/45521

7. Лозовський О.М. Особливості державного регулювання малого підприємництва в Україні. Економічний форум, №1. 2015. URL: D:/Downloads/ecfor_2015_1_23.pdf

8. Податковий кодекс України. URL: http://zakon.rada.gov.ua/laws/show/580-19

9. Юрчишена Л.В., Горлов С.І. Підвищення доходів місцевих бюджетів на основі стимулювання розвитку малого та середнього бізнесу. Фінанси. Облік. Банки. №1 (23). C. 139-202. URL: http://jfub.donnu.edu.ua/article/view/6282 